\title{
Correction to: Different clinicopathological features of non-elderly sigmoid volvulus patients
}

\author{
Ufuk Uylas $^{1}$ (D) Cuneyt Kayaalp ${ }^{1}$ (D) \\ Published online: 11 August 2020 \\ (C) Springer-Verlag GmbH Germany, part of Springer Nature 2020
}

\section{Correction to: International Journal of Colorectal Disease https://doi.org/10.1007/s00384-020-03689-6}

The article mentioned above contained an error.

The presentation of " $\leq \mathbf{6 0}$ age group" throughout the article were incorrect. The data should have been presented as "60 $\leq$ age group". The original article has been corrected.

Publisher's note Springer Nature remains neutral with regard to jurisdictional claims in published maps and institutional affiliations.

The online version of the original article can be found at https://doi.org/ 10.1007/s00384-020-03689-6

Ufuk Uylas

ufukuylas@hotmail.com

Cuneyt Kayaalp

cuneytkayaalp@hotmail.com

1 Faculty of Medicine, Gastroenterology Surgery, Inonu University, Malatya, Turkey 